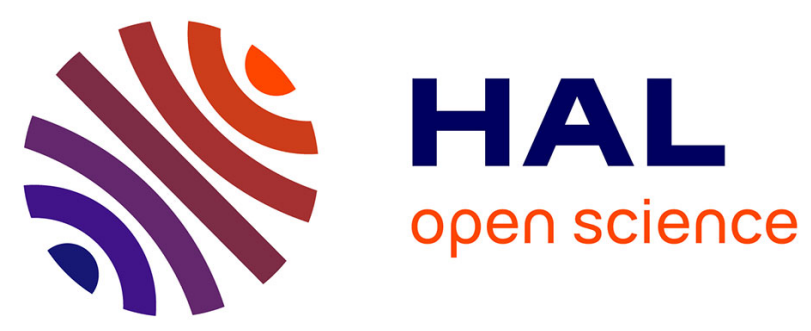

\title{
Evaluation of variants in the CHEK2, BRIP1 and PALB2 genes in an Irish breast cancer cohort
}

\author{
N. M. Mcinerney, N. Miller, A. Rowan, G. Colleran, E. Barclay, C. Curran, M.
} J. Kerin, I. P. Tomlinson, E. Sawyer

\section{- To cite this version:}

N. M. Mcinerney, N. Miller, A. Rowan, G. Colleran, E. Barclay, et al.. Evaluation of variants in the CHEK2, BRIP1 and PALB2 genes in an Irish breast cancer cohort. Breast Cancer Research and Treatment, 2009, 121 (1), pp.203-210. 10.1007/s10549-009-0540-9 . hal-00485069

\section{HAL Id: hal-00485069 \\ https://hal.science/hal-00485069}

Submitted on 20 May 2010

HAL is a multi-disciplinary open access archive for the deposit and dissemination of scientific research documents, whether they are published or not. The documents may come from teaching and research institutions in France or abroad, or from public or private research centers.
L'archive ouverte pluridisciplinaire HAL, est destinée au dépôt et à la diffusion de documents scientifiques de niveau recherche, publiés ou non, émanant des établissements d'enseignement et de recherche français ou étrangers, des laboratoires publics ou privés. 


\section{Evaluation of variants in the CHEK2, BRIP1 and PALB2 genes in an Irish breast cancer}

cohort.

Mclnerney $\mathrm{NM}^{1,2}$, Miller $\mathrm{N}^{1}$, Rowan $\mathrm{A}^{2}$, Colleran $\mathrm{G}^{1,2}$, Barclay $\mathrm{E}^{2}$, Curran $\mathrm{C}^{1}$, Kerin $\mathrm{MJ}^{1,}$ Tomlinson $\mathrm{IP}^{2}$, Sawyer $\mathrm{E}^{2,3}$.

${ }^{1}$ Department of Surgery, Clinical Science Institute, University College Hospital, Galway, Ireland ${ }^{2}$ Molecular and Population Genetics Laboratory, Wellcome Trust Centre for Human Genetics, University of Oxford, Roosevelt Drive, Oxford OX3 7BN

${ }^{3}$ Guy's, King's, St Thomas' Cancer Centre, Guy's Hospital, St Thomas's Street, London SE1 9RT, UK

Corresponding Author: Niall Mclnerney, Department of Surgery, Clinical Science Institute, University College Hospital, Galway, Ireland Fax 00353 91, Tel 00353864011740 e-mail address: nmac@ymail.com

Key Words: breast cancer, genetic susceptibility, West Ireland, CHEK2, BRIP1, PALB2

Conflict of Interest: None 


\section{Abstract}

Background: It has been proposed that rare variants within the double strand break repair genes CHEK2, BRIP1 and PALB2 predispose to breast cancer. The aim of this study was to evaluate the prevalence of these variants in an Irish breast cancer cohort and determine their contribution to the development of breast cancer in the West of Ireland.

Methods: We evaluated the presence of CHEK2_1100delC variant in 903 breast cancer cases and 1016 controls. Six previously described variants within BRIP1 and five within PALB2 were screened in 192 patients with early-onset or familial breast cancer. Where a variant was evident, it was then examined in the remainder of our 711 unselected breast cancer cases.

Results: CHEK2_1100delC was found in 5/903 (0.5\%) breast cancer cases compared to 1/1016 (0.1\%). One mutation at BRIP1 (2392 C>T) was identified in the early-onset/familial cohort. Examination of this variant in the remainder of our cohort $(711$ cases $)$ failed to identify any additional cases. None of the previously described PALB2 variants were demonstrated in the earlyonset/familial cohort.

Conclusions: We show evidence of CHEK2_1100delC and BRIP1 2392 C>T within the Irish population. CHEK2_1100delC and BRIP1 mutations incidence in Ireland is similar to that found in other unselected breast cancer cohorts from Northern European countries. We found no evidence to suggest that PALB2 mutation is an important breast cancer predisposition gene in this population. 


\section{Introduction}

Breast cancer has long been known to have a significant genetic component; females with an affected first-degree relative carry an approximately 1.8 increased relative risk compared with the general population [1]. Mutations in the high-penetrance predisposition genes $B R C A 1$ and $B R C A 2$ account for less than $20 \%$ of familial breast cancer [2]. BRCA1 and BRCA2 have roles in the double strand break repair (DSBR) pathway and DSBR genes have been screened for mutations in breast cancer cases without $B R C A 1$ or $B R C A 2$ mutations. Rare variants in three of these genes $-C H E K 2$, $B R I P 1$ and $P A L B 2$ - with allele frequencies of $0.4 \%, 0.1 \%$ and less than $0.1 \%$ respectively have been associated with breast cancer risk [3]. These variants demonstrate moderate penetrance with regard to breast cancer susceptibility with an increased relative risk of 2-4 fold [4-6].

The most extensively studied of the three breast cancer genes is CHEK2. Although many mutations in CHEK2 have been described the commonest in Northern Europeans countries is CHEK2_ $1100 \mathrm{de} / \mathrm{C}$, with an incidence of $0.7 \%$ in unselected breast cancer and $2.1 \%$ in familial breast cancer [4]. CHEK2_1100de/C is less common in Mediterranean and Asian countries [7-9]. Pharoah et al estimated the absolute risk of breast cancer by age 70 in carriers of CHEK2_ 1100 delC to be $13 \%$ compared to $5.7 \%$ in non-carriers, while in first-degree relatives it is responsible for $1.4 \%$ of the excess risk [10].

Seal et al identified 6 truncating mutations within the Fanconi anaemia $\mathrm{J}$ gene $B R I P 1$ which were estimated to confer a 2 fold increased relative risk of breast cancer in monoallelic carrriers [5]. BRIP1 mutations were present in 9/1212 breast cancer cases negative for $B R C A 1 / 2$ mutations compared with 2/2081 controls $(p=0.003)$ [5]. A nonsense mutation 2392C $>T(R 798 X)$ accounted for the majority of mutations in this gene. These findings have not, however, been replicated in more recent studies [11-19].

Study of BRCA2 revealed an associated gene PALB2 (also known as FANCN), in which biallelic mutations cause Fanconi anaemia. Rahman et al screened PALB2 in 923 familial breast cancer 
patients and identified 5 truncating mutations which were estimated to confer a 2.3 -fold increased risk of breast cancer [6]. Additional rare novel truncating mutations have also been discovered by other groups [20, 21]. The Finnish founder mutation identified by Erkko et al, c.1592de/T, has been estimated to confer a lifetime risk of breast cancer equivalent to $B R C A 2$ mutation carriers [22, 23]. The possibility of specific PALB2 variants conferring high penetrance in breast cancer was further proposed by Tischkowitz et al following their discovery of a truncating mutation PALB2 229delT [24]. These finding suggest that the relative risk of developing breast cancer previously attributed to PALB2 mutations may have been underestimated by Rahman et al. Gunnarsson et al, however, found no role for PALB2 in breast cancer susceptibility in an Icelandic cohort [25].

Although still at an early stage in the investigation of these moderate-penetrance variants, there is evidence of geographical variation in their frequencies. The existence of clinically-relevant founder mutations in some populations is possible. The West of Ireland is geographically isolated from the rest of Europe and, while it shares some of its ancestry with the UK, it has experienced less inward demographic movement [26] and is relatively homogeneous. The aims of this study were to investigate whether known variants in CHEK2, BRIP1 and PALB2 contribute to breast cancer susceptibility in the West of Ireland.

\section{Methods}

Breast cancer patients and controls from the West of Ireland were collected with appropriate ethical approval as part of the Breast cancer in Galway Genetics Study (BIGGS). Cases were not selected with regard to family history of breast or ovarian cancer, personal history of ovarian cancer, the presence of a contralateral breast cancer or other second primary cancer. All controls were from a West of Ireland lineage (as were cases) and comprised women over the age of 60 years, with no self-reported personal history of any cancer and no family history of breast or ovarian cancer. From this cohort of unselected breast cancer cases, 192 cases were identified as being at relatively high risk of having an inherited predisposition to breast cancer (cases presenting at $<42$ years old or $<55$ years old with a history of breast cancer in one or more first or second degree relative). 
DNA was purified from $10 \mathrm{ml}$ samples of blood using the Chemagic Magnetic Separation Module (Chemagen, Baesweiler, Germany) using the manufacturer's reagents. Primers (Supplementary Data, Table 1) were designed to amplify a DNA fragment of 167 base pairs across CHEK2_1100delC and Genotyper software (ABI) was used to size the fragment. Genotyping was performed in 96-well format and optimised using a known CHEK2_1100delC heterozygous control on each plate. Samples with 2 bands and any equivocal results were sequenced to confirm the result using the $A B I 3100$ automated sequencer and sequence analysis software (Applied Biosystems, CA), Figure 1.

Truncating mutations in BRIP1 and PALB2 previously identified in a UK cohort by Seal et al and Rahman et al, Table 1, were analysed by direct sequencing in the early onset/familial subset. Primers are listed in Supplementary Data, Table 1. Where a variant was identified, it was subsequently genotyped in the remaining 711 breast cancer patient samples using the KASPar SNP genotyping system (KBiosciences).

Meta-analysis data were combined using the Mantel-Haenszel method. All statistical analyses were undertaken using STATA 9.2 (Stata Corp, College Station, TX).

\section{Results}

The pathological characteristics of the whole cohort are described elsewhere [27]. From this cohort of unselected breast cancer cases, 192 cases were identified as being at relatively high risk of having an inherited predisposition to breast cancer (cases presenting at $<42$ years old or $<55$ years old with a history of breast cancer in one or more first or second degree relative). Histological information was available in all of these cases and is summarized in Table 2.

Analysis of CHEK2 
5/903 (0.5\%) CHEK2_1100delC mutations were identified in the cases and 1/1016 (0.1\%) controls (OR 5.65, 95\% Cl 0.66-48.46, $p=0.09$ 1-tailed, $p=0.11$ 2-tailed Fisher's exact test). None of these mutations occurred in the early onset/familial subgroup. The clinical features of these individuals are summarized in Table 3. One CHEK2_1100delC mutation carrier was diagnosed at 60 and had a family history of breast cancer on her paternal side, with an aunt, two first cousins and grandmother being affected.The remaining four $\mathrm{CHEK} 2 \_1100 \mathrm{del}$ C mutation carriers had no family history of breast cancer but two had a family history of leukaemia. The control carrier was an 82 year old female with no personal or family history of cancer.

Population variation is evident in the prevalence of CHEK2_1100de/C, with the highest incidence reported in Dutch cohorts (3.8\% cases and $1.6 \%$ controls) and a negative association with breast cancer susceptibility demonstrated in a Spanish cohort $[4,7]$. We have combined our data with that of previous meta- analyses carried out by the CHEK2 Breast Cancer Case-Control Consortium and Weischer et al [4, 28], excluding any none European studies and any familial breast cancer studies, Figure 3 and Supplementary Data Table 2. This gives an overall odds ratio is 2.1 (95 $\mathrm{Cl} 1.7-2.7)$ similar to that found by Weischer et al (OR $2.4,95 \% \mathrm{Cl} 1.8-3.2)$ and shows that the relative risk associated with CHEK2_1100delC in the Irish population is similar to other Northern / Central European populations. The incidence of CHEK2_1100de/C in West Ireland is similar $\left(\chi^{2}\right.$ test $p=0.13)$ to that in the UK $(1.2 \%$ in cases and $0.53 \%$ controls, $A B C$ study $)$ but significantly less $\left(\chi^{2}\right.$ test $p<0.0001$ ) than unselected cases series from the Netherlands (RMOTC study - cases $3.8 \%$, controls 1.6\%, Prospect study - cases 3.3\%, controls 0\%), Supplementary Data Table 2, [4].

\section{BRIP1 Analysis}

$1 / 192(0.5 \%)$ of the early-onset/familial patients was found to have a BRIP1 mutation $(2392 \mathrm{C}>\mathrm{T}$, Figure 2). This patient was diagnosed with ductal breast cancer at age 53 and had a sister affected at 55 years of age. We then examined this variant, $B R I P 12392 C>T$, in the remainder of our cohort of 711 cases, but none was found. None of the other BRIP1 mutations previously found by Rahman et al were present in the early-onset/familial series and were therefore not screened for in the 
remaining cases. Table 4 summarizes the findings from other studies. Very few studies have looked for BRIP1 mutations and due to the small numbers a meta-analysis is not possible. However there was no evidence of heterogeneity between studies $\left(p=0.145\right.$, heterogeneity $\chi^{2}$ test) suggesting BRIP1 is a rare breast cancer predisposition gene. The finding of one BRIP1 mutation in our subset of early-onset/familial breast cancer and no other mutations in the whole cohort is consistent with the population frequency of $0.1 \%$ previously estimated.

\section{PALB2 Analysis}

None of the PALB2 variants previously described Rahman et al were present in the earlyonset/familial series. The findings of other studies are summarized in Table 5. We performed a meta-analysis of these studies ( studies with the same controls were considered together) which showed an overall odds ratio of 8.92 (95 $\mathrm{Cl} 3.4-23.4)$. There was no evidence of heterogeneity between studies $\left(p=0.11\right.$, heterogeneity $\chi^{2}$ test $)$.

\section{Discussion}

We have shown an increased risk of breast cancer with CHEK2_1100delC mutations in the West of Ireland, similar to that found in other Northern and Central European countries. The recent metaanalysis of CHEK2_1100delC by Weischer et al, [28], demonstrated that unselected and early onset cases had a similar relative risk of breast cancer (OR 2.7, 95\% $\mathrm{Cl} 2.1-3.4 ; \mathrm{OR} 2.6,95 \% \mathrm{Cl}$ 1.3-5.5 respectively), however the familial cases (defined as at least one first and one second degree relative with breast cancer, a male relative with breast cancer, or at least one patient case of female breast cancer and one patient case of ovarian cancer among relatives) had a much higher relative risk (OR 4.8, 95\% $\mathrm{Cl} 3.3-7.2, \mathrm{p}<0.0001)$ ). We did not see this in our series, in contrast our subset of familial/early onset cases showed no CHEK2_1100delC mutation. However this is likely to be due to the small numbers and the inclusion of early onset breast cancers in our 'high risk' group.

To our knowledge this is the first study to replicate the identification by Seal et al of the BRIP1 2392 $C>T$ mutation. We analysed those variants in BRIP1 identified by Seal et al due to the relative 
homogeneity between the Irish and UK populations [5]. The BRIP1 $2392 C>T$ mutation was the most common mutation found by Seal et al, accounting for 5 of the 9 mutations they detected. It has not been demonstrated in any population outside Ireland or the UK, suggesting it may be specific to these populations.

Like CHEK2_1100de/C there appears to be considerable population variation in the incidence of PALB2 mutations, with a particularly high incidence in Finland (1592delT) and very few in the Icelandic and Irish populations. However the Icelandic study [25] and our study did not screen the whole gene for novel mutations, it is therefore possible that these populations contain as yet unidentified mutations.

In conclusion this is the first study of proposed moderate-penetrance breast cancer susceptibility variants in an Irish cohort of breast cancer patients. 0.5\% of cases carried CHEK2_1100delC, compared with $0.1 \%$ of controls, a similar prevalence to that found in the UK. BRIP and PALB2 mutation appear to be rare in the Irish breast cancer population as they are in other populations, but mutation screening of these genes in a large familial Irish cohort will be required to fully establish what possible role mutations in these genes play in familial breast cancer in Ireland.

\section{Acknowledgements}

We are grateful to the patients in the study and colleagues involved in patient ascertainment and sample collection. Help was also kindly provided by the Equipment Park, London Research Institute, Cancer Research UK. NM and GC were funded by the National Breast Cancer Research Institute, Ireland. ES is funded by a Department of Health Clinician Award and via the National Institute for Health Research (NIHR) comprehensive Biomedical Research Centre award to Guy's \& St Thomas' NHS Foundation Trust in partnership with King's College London and King's College Hospital NHS Foundation Trust 
References

1. Collaborative Group on Hormonal Factors in Breast Cancer: Familial breast cancer: collaborative reanalysis of individual data from 52 epidemiological studies including 58,209 women with breast cancer and 101,986 women without the disease. Lancet 2001, 358(9291):1389-1399.

2. Anglian Breast Cancer Study Group: Prevalence and penetrance of BRCA1 and BRCA2 mutations in a population-based series of breast cancer cases. . Br J Cancer 2000, 83(10):1301-1308.

3. Turnbull C, Rahman N: Genetic predisposition to breast cancer: past, present, and future. Anпи Rev Genomics Hum Genet 2008, 9:321-345.

4. CHEK2 Breast Cancer Case-Control Consortium: CHEK2*1100delC and susceptibility to breast cancer: a collaborative analysis involving 10,860 breast cancer cases and 9,065 controls from 10 studies. Am J Hum Genet 2004, 74(6):1175-1182.

5. Seal S, Thompson D, Renwick A, Elliott A, Kelly P, Barfoot R, Chagtai T, Jayatilake H, Ahmed M, Spanova K et al: Truncating mutations in the Fanconi anemia J gene BRIP1 are low-penetrance breast cancer susceptibility alleles. Nat Genet 2006, 38(11):1239-1241.

6. Rahman N, Seal S, Thompson D, Kelly P, Renwick A, Elliott A, Reid S, Spanova $\mathrm{K}$, Barfoot $\mathrm{R}$, Chagtai $\mathrm{T}$ et al: PALB2, which encodes a BRCA2-interacting protein, is a breast cancer susceptibility gene. Nat Genet 2007, 39(2):165-167.

7. Osorio A, Rodriguez-Lopez R, Diez O, de la Hoya M, Ignacio Martinez J, Vega A, Esteban-Cardenosa E, Alonso C, Caldes T, Benitez J: The breast cancer lowpenetrance allele 1100delC in the CHEK2 gene is not present in Spanish familial breast cancer population. Int J Cancer 2004, 108(1):54-56.

8. Bellosillo B, Tusquets I, Longaron R, Perez-Lezaun A, Bellet M, Fabregat X, Serrano S, Sole F: Absence of CHEK2 mutations in Spanish families with hereditary breast cancer. Cancer Genet Cytogenet 2005, 161(1):93-95.

9. Chen W, Yurong S, Liansheng N: Breast cancer low-penetrance allele 1100delC in the CHEK2 gene: Not present in the Chinese familial breast cancer population. Adv Ther 2008, 25(5):496-501.

10. Pharoah PD, Antoniou AC, Easton DF, Ponder BA: Polygenes, risk prediction, and targeted prevention of breast cancer. N Engl J Med 2008, 358(26):27962803.

11. Cao AY, Huang J, Hu Z, Li WF, Ma ZL, Tang LL, Zhang B, Su FX, Zhou J, Di GH et al: Mutation analysis of BRIP1/BACH1 in BRCA1/BRCA2 negative Chinese women with early onset breast cancer or affected relatives. Breast Cancer Res Treat 2008.

12. Guenard F, Labrie Y, Ouellette G, Joly Beauparlant C, Simard J, Durocher F: Mutational analysis of the breast cancer susceptibility gene BRIP1 /BACH1/FANCJ in high-risk non-BRCA1/BRCA2 breast cancer families. $J$ Hum Genet 2008, 53(7):579-591. 
13. Rutter JL, Smith AM, Davila MR, Sigurdson AJ, Giusti RM, Pineda MA, Doody MM, Tucker MA, Greene MH, Zhang $\mathrm{J}$ et al: Mutational analysis of the BRCA1-interacting genes ZNF350/ZBRK1 and BRIP1/BACH1 among BRCA1 and BRCA2-negative probands from breast-ovarian cancer families and among early-onset breast cancer cases and reference individuals. Hum Mutat 2003, 22(2):121-128.

14. Sigurdson AJ, Hauptmann M, Chatterjee N, Alexander BH, Doody MM, Rutter JL, Struewing JP: Kin-cohort estimates for familial breast cancer risk in relation to variants in DNA base excision repair, BRCA1 interacting and growth factor genes. BMC Cancer 2004, 4:9.

15. Song H, Ramus SJ, Kjaer SK, Hogdall E, Dicioccio RA, Whittemore AS, McGuire V, Hogdall C, Jacobs IJ, Easton DF et al: Tagging single nucleotide polymorphisms in the BRIP1 gene and susceptibility to breast and ovarian cancer. PLoS ONE 2007, 2(3):e268.

16. Lewis AG, Flanagan J, Marsh A, Pupo GM, Mann G, Spurdle AB, Lindeman GJ, Visvader JE, Brown MA, Chenevix-Trench G: Mutation analysis of FANCD2, BRIP1/BACH1, LMO4 and SFN in familial breast cancer. Breast Cancer Res 2005, 7(6):R1005-1016.

17. Vahteristo P, Yliannala K, Tamminen A, Eerola H, Blomqvist C, Nevanlinna H: BACH1 Ser919Pro variant and breast cancer risk. BMC Cancer 2006, 6:19.

18. Frank B, Hemminki K, Meindl A, Wappenschmidt B, Sutter C, Kiechle M, Bugert P, Schmutzler RK, Bartram CR, Burwinkel B: BRIP1 (BACH1) variants and familial breast cancer risk: a case-control study. BMC Cancer 2007, 7:83.

19. Garcia-Closas M, Egan KM, Newcomb PA, Brinton LA, Titus-Ernstoff L, Chanock S, Welch R, Lissowska J, Peplonska B, Szeszenia-Dabrowska N et al: Polymorphisms in DNA double-strand break repair genes and risk of breast cancer: two population-based studies in USA and Poland, and meta-analyses. Hum Genet 2006, 119(4):376-388.

20. Garcia MJ, Fernandez V, Osorio A, Barroso A, Llort G, Lazaro C, Blanco I, Caldes T, de la Hoya M, Ramon YCT et al: Analysis of FANCB and FANCN/PALB2 Fanconi Anemia genes in BRCA1/2-negative Spanish breast cancer families. Breast Cancer Res Treat 2008.

21. Foulkes WD, Ghadirian P, Akbari MR, Hamel N, Giroux S, Sabbaghian N, Darnel A, Royer R, Poll A, Fafard E et al: Identification of a novel truncating PALB2 mutation and analysis of its contribution to early-onset breast cancer in French-Canadian women. Breast Cancer Res 2007, 9(6):R83.

22. Erkko H, Xia B, Nikkila J, Schleutker J, Syrjakoski K, Mannermaa A, Kallioniemi A, Pylkas K, Karppinen SM, Rapakko K et al: A recurrent mutation in PALB2 in Finnish cancer families. Nature 2007, 446(7133):316319.

23. Erkko H, Dowty JG, Nikkila J, Syrjakoski K, Mannermaa A, Pylkas K, Southey MC, Holli K, Kallioniemi A, Jukkola-Vuorinen A et al: Penetrance Analysis of the PALB2 c.1592delT Founder Mutation. Clin Cancer Res 2008, 14(14):46674671.

24. Tischkowitz M, Xia B, Sabbaghian N, Reis-Filho JS, Hamel N, Li G, van Beers EH, Li L, Khalil T, Quenneville LA et al: Analysis of PALB2/FANCN- 
associated breast cancer families. Proc Natl Acad Sci U S A 2007, 104(16):6788-6793.

25. Gunnarsson H, Arason A, Gillanders EM, Agnarsson BA, Johannesdottir G, Johannsson OT, Barkardottir RB: Evidence against PALB2 involvement in Icelandic breast cancer susceptibility. J Negat Results Biomed 2008, 7:5.

26. Hill EW, Jobling MA, Bradley DG: Y-chromosome variation and Irish origins. Nature 2000, 404(6776):351-352.

27. McInerney N, Colleran G, Rowan A, Walther A, Barclay E, Spain S, Jones AM, Tuohy S, Curran C, Miller $\mathrm{N}$ et al: Low penetrance breast cancer predisposition SNPs are site specific. Breast Cancer Res Treat 2008.

28. Weischer M, Bojesen SE, Ellervik C, Tybjaerg-Hansen A, Nordestgaard BG: CHEK2*1100delC genotyping for clinical assessment of breast cancer risk: meta-analyses of $\mathbf{2 6 , 0 0 0}$ patient cases and 27,000 controls. J Clin Oncol 2008, 26(4):542-548.

29. De Nicolo A, Tancredi M, Lombardi G, Flemma CC, Barbuti S, Di Cristofano C, Sobhian B, Bevilacqua G, Drapkin R, Caligo MA: A novel breast cancerassociated BRIP1 (FANCJ/BACH1) germ-line mutation impairs protein stability and function. Clin Cancer Res 2008, 14(14):4672-4680.

30. Cao AY, Huang J, Hu Z, Li WF, Ma ZL, Tang LL, Zhang B, Su FX, Zhou J, Di GH et al: The prevalence of PALB2 germline mutations in BRCA1/BRCA2 negative Chinese women with early onset breast cancer or affected relatives. Breast Cancer Res Treat 2008.

31. Sluiter M, Mew S, van Rensburg EJ: PALB2 sequence variants in young South African breast cancer patients. Fam Cancer 2009.

32. Heikkinen T, Karkkainen H, Aaltonen K, Milne RL, Heikkila P, Aittomaki K, Blomqvist C, Nevanlinna $\mathrm{H}$ : The breast cancer susceptibility mutation PALB2 1592delT is associated with an aggressive tumor phenotype. Clin Cancer Res 2009, 15(9):3214-3222.

33. Vahteristo P, Bartkova J, Eerola H, Syrjakoski K, Ojala S, Kilpivaara O, Tamminen A, Kononen J, Aittomaki K, Heikkila P et al: A CHEK2 genetic variant contributing to a substantial fraction of familial breast cancer. Am J Hum Genet 2002, 71(2):432-438.

34. de Jong MM, Nolte IM, Te Meerman GJ, van der Graaf WT, Oosterom E, Bruinenberg M, Steege G, Oosterwijk JC, van der Hout AH, Boezen HM et al: No increased susceptibility to breast cancer from combined CHEK2 1100delC genotype and the HLA class III region risk factors. Eur J Cancer 2005, 41(12):1819-1823.

35. Meijers-Heijboer H, van den Ouweland A, Klijn J, Wasielewski M, de Snoo A, Oldenburg R, Hollestelle A, Houben M, Crepin E, van Veghel-Plandsoen M et al: Low-penetrance susceptibility to breast cancer due to CHEK2(*)1100delC in noncarriers of BRCA1 or BRCA2 mutations. Nat Genet 2002, 31(1):55-59.

36. Van Binst T GG, Sermijn E, Van Hassel G, De Neef K, Bonduelle M, Fontaine C, Teugels E, and De Greve JJ: The CHEK2*1100delC mutation predisposes for early-onset breast cancer in breast cancer families. Breast Cancer Res Treat 2004, 88: S151. 
37. Baeyens A, Claes K, Willems P, De Ruyck K, Thierens H, Vral A: Chromosomal radiosensitivity of breast cancer with a CHEK2 mutation. Cancer Genet Cytogenet 2005, 163(2):106-112.

38. Kleibl Z, Novotny J, Bezdickova D, Malik R, Kleiblova P, Foretova L, Petruzelka L, Ilencikova D, Cinek P, Pohlreich P: The CHEK2 c.1100delC germline mutation rarely contributes to breast cancer development in the Czech Republic. Breast Cancer Res Treat 2005, 90(2):165-167.

39. Rashid MU, Jakubowska A, Justenhoven C, Harth V, Pesch B, Baisch C, Pierl $\mathrm{CB}$, Bruning T, Ko Y, Benner A et al: German populations with infrequent CHEK2*1100delC and minor associations with early-onset and familial breast cancer. Eur J Cancer 2005, 41(18):2896-2903.

40. Cybulski C, Wokolorczyk D, Huzarski T, Byrski T, Gronwald J, Gorski B, Debniak T, Masojc B, Jakubowska A, van de Wetering T et al: A deletion in CHEK2 of 5,395 bp predisposes to breast cancer in Poland. Breast Cancer Res Treat 2007, 102(1):119-122.

41. Einarsdottir K, Humphreys K, Bonnard C, Palmgren J, Iles MM, Sjolander A, Li Y, Chia KS, Liu ET, Hall P et al: Linkage disequilibrium mapping of CHEK2: common variation and breast cancer risk. PLoS Med 2006, 3(6):e168.

42. Weischer M, Bojesen SE, Tybjaerg-Hansen A, Axelsson CK, Nordestgaard BG: Increased risk of breast cancer associated with CHEK2*1100delC. J Clin Oncol 2007, 25(1):57-63. 
Table 1: Mutations analysed in CHEK2, BRIP1 and PALB2

\begin{tabular}{|c|c|c|c|c|c|}
\hline Gene & Mutation & Alteration & $\begin{array}{c}\text { Galway } \\
\text { Early Onset/ } \\
\text { Familial }\end{array}$ & $\begin{array}{c}\text { Galway } \\
\text { Unselected }\end{array}$ & Controls \\
\hline CHEK2 & 1100delC & & 0/192 & $5 / 711$ & $1 / 1016$ \\
\hline BRIP & $2392 \mathrm{C}>\mathrm{T}$ & R798X & $1 / 192$ & $0 / 711$ & - \\
\hline BRIP & $141 \mathrm{del} C$ & Premature Truncation & 0/192 & - & - \\
\hline BRIP & IVS17+2insT & Exon 17 or 18 skipped & 0/192 & - & - \\
\hline BRIP & 2255delAA & Premature Truncation & 0/192 & - & - \\
\hline BRIP & 2108delAinsTCC & Premature Truncation & 0/192 & - & - \\
\hline BRIP & 2008insT & Premature Truncation & 0/192 & - & - \\
\hline PALB2 & $2386 \mathrm{G}>\mathrm{T}$ & G796X & 0/192 & - & - \\
\hline PALB2 & 2982 ins T & A995 fs & 0/192 & - & - \\
\hline PALB2 & $3113 G>A$ & W1038X & 0/192 & - & - \\
\hline PALB2 & 3116 delA & N1039 fs & 0/192 & - & - \\
\hline PALB2 & $3549 C>G$ & Y1183X & 0/192 & - & - \\
\hline
\end{tabular}


Table 2: Histological Characteristics in 192 patients identified with early onset/familial breast cancer. Estrogen receptor status is denoted by ER.

\begin{tabular}{|c|c|}
\hline $\begin{array}{l}\text { Histological } \\
\text { Characteristics }\end{array}$ & $\%$ of Cases \\
\hline Average Age & $42(25-55)$ \\
\hline Ductal & 77 \\
\hline Lobular & 7 \\
\hline Unknown & 16 \\
\hline Grade 1 & 9 \\
\hline Grade 2 & 30 \\
\hline Grade 3 & 36 \\
\hline Unknown grade & 25 \\
\hline ER positive & 51 \\
\hline ER Negative & 25 \\
\hline ER unknown & 24 \\
\hline Node positive & 39 \\
\hline Node negative & 46 \\
\hline Node Unknown & 28 \\
\hline $\begin{array}{l}\text { Family History of } 1^{\text {st }} \text { degree relative with } \\
\text { breast cancer }\end{array}$ & 18 \\
\hline $21^{\text {st }}$ degree relatives affected & 3 \\
\hline $31^{\text {st }}$ degree relatives affected & 1 \\
\hline $\begin{array}{l}\text { Family History of } 2^{\text {nd }} \text { degree relative with } \\
\text { breast cancer }\end{array}$ & 36 \\
\hline $2 \times 2^{\text {nd }}$ degree relatives affected & 10 \\
\hline $3 \times 2^{\text {nd }}$ degree relatives affected & 2 \\
\hline Both $1^{\text {st }}$ and $2^{\text {nd }}$ degree relatives affected & 5 \\
\hline Bilateral & 10 \\
\hline
\end{tabular}


Table 3: Clinicopathological details of CHEK2_1100delC mutation carriers;

\begin{tabular}{|c|c|c|c|c|c|}
\hline Clinical Details & 1 & 2 & 3 & 4 & 5 \\
\hline Age at Diagnosis & 67 & 71 & 56 & 55 & 60 \\
\hline Histological Type & Ductal & UNK & Ductal & Ductal & Lobular \\
\hline Grade & UNK & UNK & 3 & UNK & UNK \\
\hline ER & NEG & UNK & POS & POS & POS \\
\hline PR & NEG & UNK & POS & POS & POS \\
\hline HER2 & NEG & UNK & NEG & NEG & NEG \\
\hline $\begin{array}{l}\text { Family History } \\
\text { of breast cancer }\end{array}$ & No & No & No & No & $\begin{array}{l}\text { Aunt, } 2 \text { First Cousins, } \\
\text { Grandmother. }\end{array}$ \\
\hline $\begin{array}{l}\text { Family History } \\
\text { of any cancer }\end{array}$ & $\begin{array}{c}\text { Sister-Colon } \\
\text { Mother-Leukaemia }\end{array}$ & No & No & $\begin{array}{l}\text { Brother- Testicular } \\
\text { Mother- Leukaemia }\end{array}$ & No \\
\hline
\end{tabular}


Table 4: Summary of studies looking at BRIP1 mutations in breast cancer

\begin{tabular}{|c|c|c|c|c|c|c|}
\hline & BRIP1 & & & & & \\
\hline Country & Author & $\begin{array}{l}\text { Whole gene } \\
\text { screened }\end{array}$ & $\begin{array}{l}\text { Truncating } \\
\text { Mutations } \\
\text { Detected }\end{array}$ & Cases & Controls & \\
\hline UK & Seal[5] & Yes & $\begin{array}{l}\text { 141del C } \\
\text { 2392 C>T } \\
\text { IVS17+INST } \\
\text { 2008insT } \\
\text { 2255del AA } \\
\text { 2108delAinsTCC }\end{array}$ & $9 / 1,212$ & $2 / 2,081$ & Familial \\
\hline China & Cao[11] & Yes & & $0 / 357$ & $0 / 864$ & Familial \\
\hline Canada & Guenard[12] & & & $0 / 96$ & $0 / 73$ & Familial \\
\hline USA & Rutter[13] & Yes & & $0 / 58$ & $0 / 30$ & Familial \\
\hline Italy & De Nicolo[29] & Yes & $\begin{array}{l}\text { 2992- } \\
\text { 2995delAAGA }\end{array}$ & $1 / 49$ & & Familial \\
\hline Australia & Lewis[16] & Yes & $\begin{array}{l}3401 \text { delC } \\
\text { (did not } \\
\text { segregate with } \\
\text { breast cancer) }\end{array}$ & $\begin{array}{l}1 / 75 \\
\text { (did not } \\
\text { segregate } \\
\text { with } \\
\text { breast } \\
\text { cancer) }\end{array}$ & $0 / 93$ & Familial \\
\hline Finland & $\begin{array}{l}\text { Vahteristo et al } \\
{[17]}\end{array}$ & Yes & & $0 / 43$ & & Familial \\
\hline Ireland & BIGGS & $\begin{array}{l}\text { No only } \\
\text { 141del C } \\
2392 \text { C>T } \\
\text { IVS17+INST } \\
2008 \text { insT } \\
\text { 2255del AA } \\
\text { 2108delAinsTCC }\end{array}$ & $2392 C>T$ & $1 / 192$ & & $\begin{array}{l}\text { Familial/ } \\
\text { early onset }\end{array}$ \\
\hline
\end{tabular}


Table 5: Summary of studies looking at PALB2 mutations in breast cancer

\begin{tabular}{|c|c|c|c|c|c|c|}
\hline Country & Author & $\begin{array}{l}\text { Whole gene } \\
\text { screened }\end{array}$ & $\begin{array}{l}\text { Truncating } \\
\text { Mutations } \\
\text { Detected }\end{array}$ & Cases & Controls & \\
\hline UK & Rahman [6] & Yes & $\begin{array}{l}2386 G>T \\
2982 i n s T \\
3113 G>A \\
3116 \text { delA } \\
3549 C>G\end{array}$ & $10 / 923$ & $0 / 1,084$ & Familial \\
\hline China & Cao[30] & Yes & $\begin{array}{l}\text { 751C>T } \\
\text { 1050_1051del } \\
\text { AAinsTCT }\end{array}$ & $3 / 360$ & $0 / 864$ & Familial \\
\hline Canada & Foulkes[21] & Yes & $2323 \mathrm{C}>\mathrm{T}$ & $\begin{array}{l}1 / 50 \\
2 / 356\end{array}$ & $0 / 6440$ & $\begin{array}{l}\text { Familial } \\
\text { Early onset }\end{array}$ \\
\hline Spain & Garcia[20] & Yes & $\begin{array}{l}\text { 1056_1057del } \\
\text { GA }\end{array}$ & $1 / 95$ & & Familial \\
\hline USA & Tishkowitz[24] & Yes & 229delT & $1 / 68$ & & Familial \\
\hline $\begin{array}{l}\text { South } \\
\text { Africa }\end{array}$ & Sluiter[31] & Yes & 697delG & $1 / 48$ & & Early onset \\
\hline Iceland & Gunnarsson[25] & $\begin{array}{l}\text { No } \\
1592 \text { delT } \\
\text { only } \\
\text { screened }\end{array}$ & & $\begin{array}{l}0 / 61 \\
0 / 638\end{array}$ & & $\begin{array}{l}\text { Familial } \\
\text { Unselected }\end{array}$ \\
\hline Finland & Erkko[22] & Yes & 1592delT & $\begin{array}{l}3 / 113 \\
18 / 1918\end{array}$ & $6 / 2501$ & $\begin{array}{l}\text { Familial } \\
\text { Unselected }\end{array}$ \\
\hline Finland & Heikkinen[32] & $\begin{array}{l}\text { No } \\
1592 \text { delT } \\
\text { only } \\
\text { screened }\end{array}$ & 1592delT & $\begin{array}{l}19 / 947 \\
8 / 1274\end{array}$ & $2 / 1079$ & $\begin{array}{l}\text { Familial } \\
\text { Unselected }\end{array}$ \\
\hline Ireland & BIGGS & $\begin{array}{l}\text { No } \\
2386 G>T \\
2982 i n s T \\
3113 G>A \\
3116 \text { delA } \\
3549 C>G \\
\text { Sreened }\end{array}$ & & $0 / 192$ & & $\begin{array}{l}\text { Familial/ } \\
\text { early onset }\end{array}$ \\
\hline
\end{tabular}




\section{Figure Legends:}

\section{Figure 1}

(A): Normal nucleotide sequence at nucleotide 1100 in the CHEK2 gene as indicated by the presence of a cytosine at position 1100 .

(B): Single base cytosine deletion at nucleotide 1100 resulting in abrogated protein function in CHEK2_1100delC mutation carriers.

(C): CHEK2_1100delC mutation detected by PCR - 167bp fragments in normal individuals and additional peaks at $166 \mathrm{bp}$ indicating deletion of $1 \mathrm{bp}$ in mutation carrier.

\section{Figure 2}

(A): Nucleotide sequence at position 2392 in the BRIP1 gene in the DNA of normal individual.

(B): BRIP1 2392 mutation demonstrating the C-T transition at nucleotide 2392 resulting in the generation of a stop codon in the encoded protein.

Figure 3: Meta-analysis of CHEK2 European studies (excluding familial studies)

Figure 4: Meta-analysis of PALB2 studies 
Figure 1

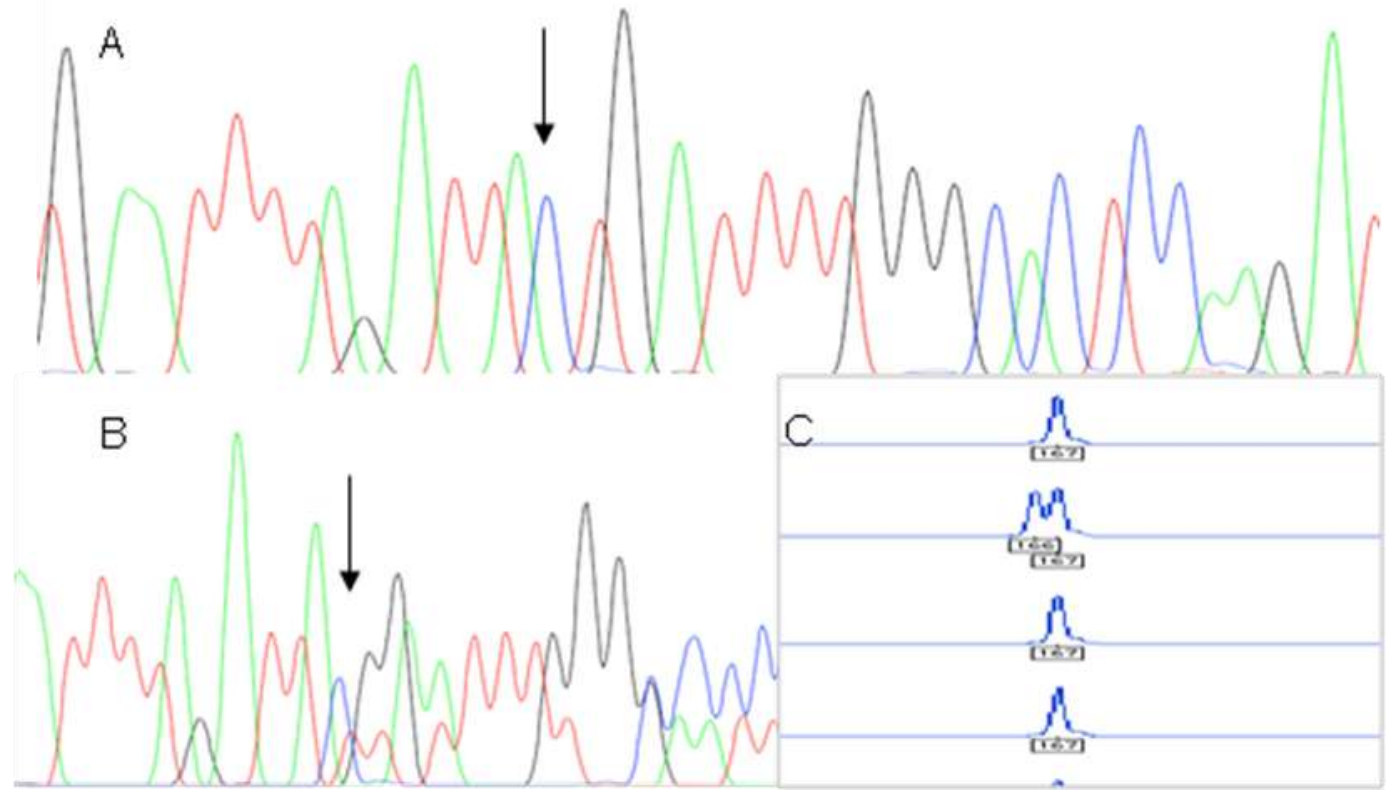


Figure 2
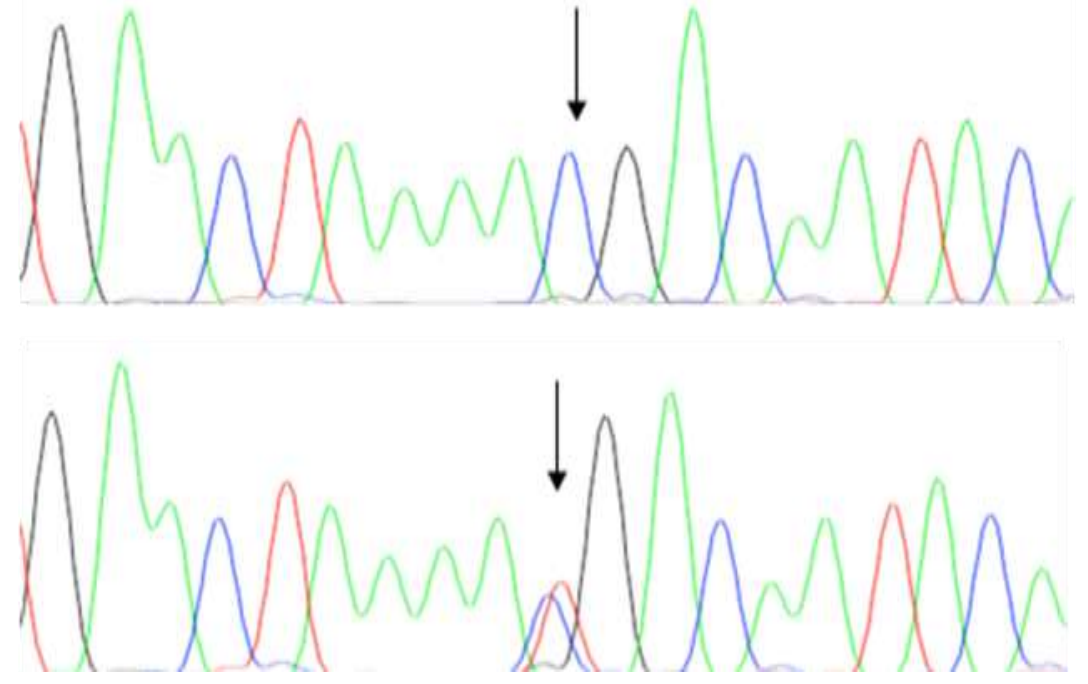
Figure 3: Meta-analysis of CHEK2 European studies (excluding familial studies).

\section{Odds ratio meta-analysis plot [random effects]}

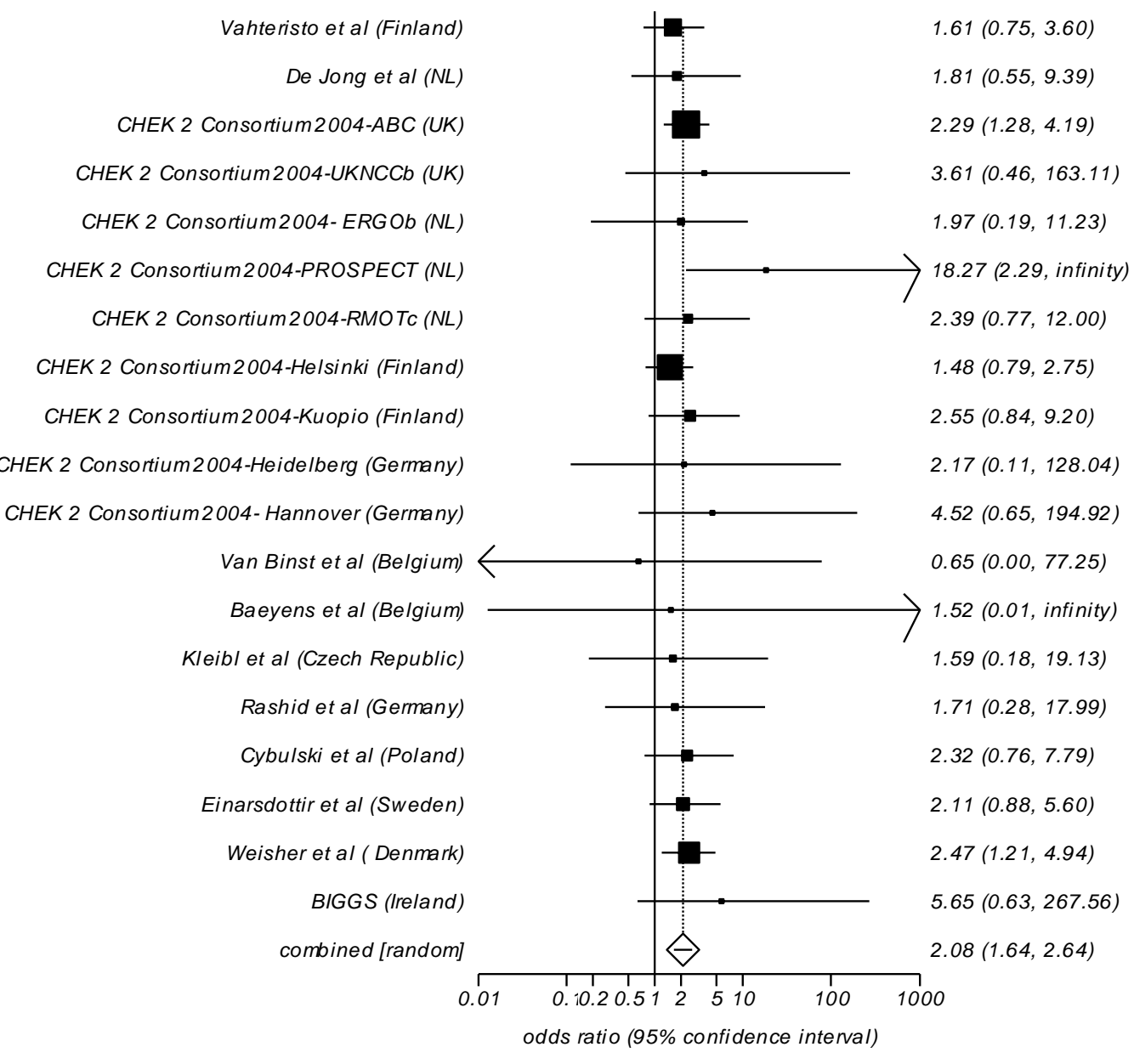


Figure 4: Meta-analysis of PALB2 studies

Odds ratio meta-analysis plot [random effects]

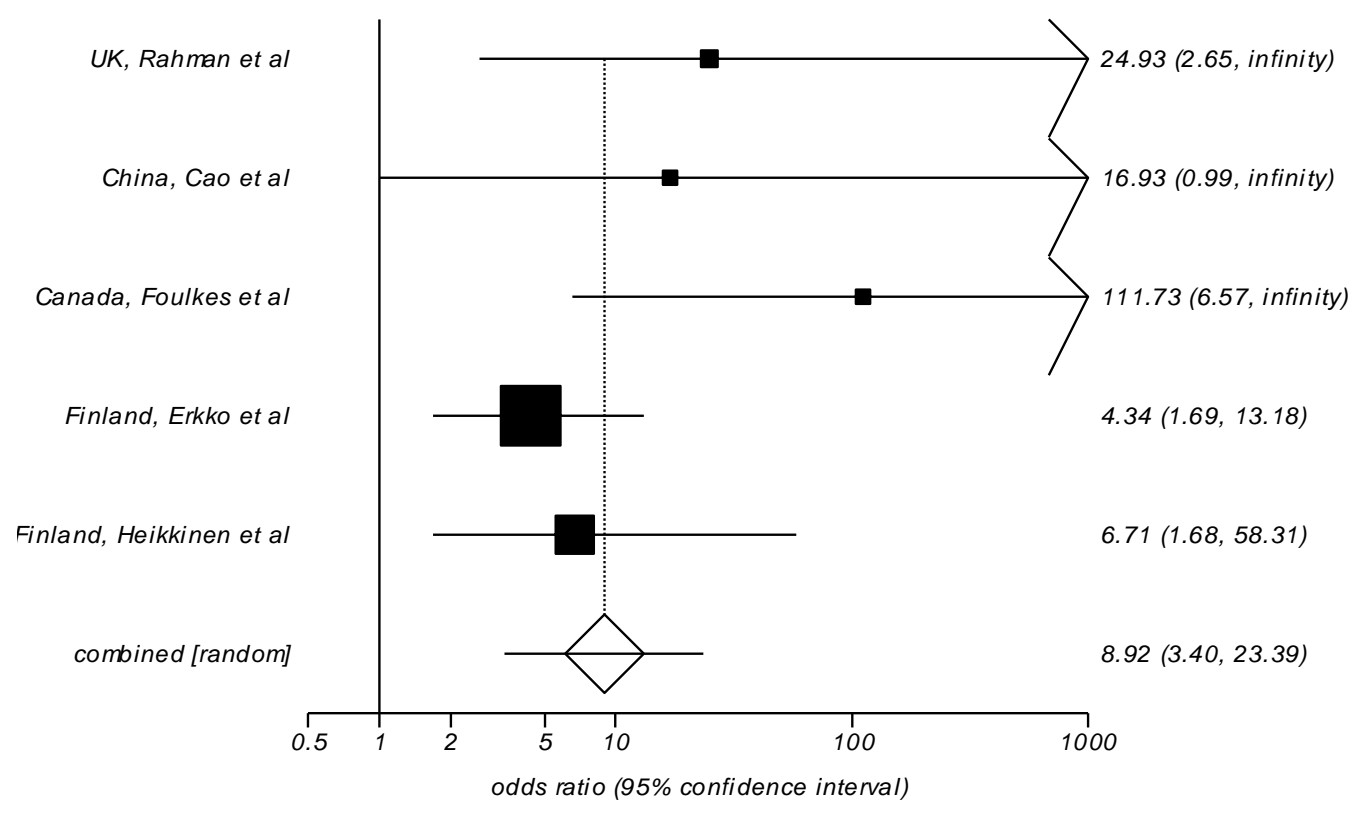


Supplementary Table 1: Primers used for CHEK2_1100deIC, BRIP1 and PALB2 mutations

\begin{tabular}{|c|c|}
\hline CHEK2-1100delC-f & TGTCTTCTTGGACTGGCAGA \\
\hline CHEK2-1100delC-r & TTCAGGCGCCAAGTAGGTGG \\
\hline BRIP1-2392 C>T-f & TGAAAAACAAAATAAAATCTCTACCC \\
\hline BRIP1-2392 C>T-r & ATACCACTGACGGCCAGGTA \\
\hline BRIP1-141 del C-f & TCAGAGGATTAAACAGCAAGCA \\
\hline BRIP1-141 del C-r & CACTAAGAGATTGTTGCCATGC \\
\hline BRIP1-IVS17+2-146-f & TTAAACCAGGCCCTTGGTAG \\
\hline BRIP1-IVS17+2-146-r & CCAGTTCCTATGGTTCCAGTT \\
\hline BRIP1-2008insT-99-f & GGTTTGGGTTGGTACCATTG \\
\hline BRIP1-2008insT-99-r & GCTCCCACTTCATCTTGGAA \\
\hline BRIP1-2255delAA-114-f & GAACCACAGGGAGGAGAAAA \\
\hline BRIP1-2255delAA-114-r & TTTTCACCGACCATGAAATAA \\
\hline BRIP1-2108delA-124-f & GCCGTAGTCACATTGGCTTA \\
\hline BRIP1-2108delA-124-r & CCAGTAGAGAGCCAACGTTCTT \\
\hline PALB2-2386-f & AGCCCAGCAAAACCACATAC \\
\hline PALB2-2386-r & TCGACGGAATGTTTATGCAG \\
\hline PALB2-3113-f & AAGGGATGCAAGAAGCTCTG \\
\hline PALB2-3113-r & CACCTGGGTGATAGGAGGAG \\
\hline PALB2-3549-f & GGCTGGACAAAAAGATGGAA \\
\hline PALB2-3549-r & CATCCAAGATCAGTGGTGCT \\
\hline PALB2-2982-f & CTTGGCCTGACAAAGAGGAG \\
\hline PALB2-2982-r & CCCAACTTTCTCTGAAACCTGT \\
\hline BRIPR798X_ALT (KASPar) & GAAGGTGACCAAGTTCATGCTAATTTTGAATGGTGGTCATTGTATTGTCA \\
\hline BRIPR798X_ALC (KASPar) & GAAGGTCGGAGTCAACGGATTTTGAATGGTGGTCATTGTATTGTCG \\
\hline BRIPR798X_C1 (KASPar) & ATATTTTAAAATTATTAGGTTGAACTAAAA \\
\hline
\end{tabular}


Supplementary Table 2: Summary of Northern/Central European CHEK2_1100delC studies ( excluding all familial and early onset studies)

\begin{tabular}{|c|c|c|c|c|c|c|c|}
\hline Study & Country & Cases & total & $\%$ & Controls & total & $\%$ \\
\hline Vahteristo et al[33] & Finland & 21 & 1035 & 2.0 & 12 & 943 & 1.3 \\
\hline De Jong et al[34] & $\mathrm{NL}$ & 28 & 962 & 2.9 & 3 & 184 & 1.6 \\
\hline CHEK 2 Consortium 2004-ABC[4] & UK & 35 & 2886 & 1.2 & 20 & 3749 & 0.5 \\
\hline $\begin{array}{l}\text { CHEK } 2 \text { Consortium 2004- } \\
\text { UKNCCb[35] }\end{array}$ & UK & 7 & 564 & 1.2 & 1 & 288 & 0.3 \\
\hline $\begin{array}{l}\text { CHEK } 2 \text { Consortium 2004- } \\
\text { ERGO[35] }\end{array}$ & $\mathrm{NL}$ & 2 & 79 & 2.5 & 6 & 460 & 1.3 \\
\hline $\begin{array}{l}\text { CHEK } 2 \text { Consortium 2004- } \\
\text { PROSPECT[4] }\end{array}$ & $\mathrm{NL}$ & 35 & 1066 & 3.3 & 0 & 265 & 0.0 \\
\hline $\begin{array}{l}\text { CHEK } 2 \text { Consortium 2004- } \\
\text { RMOTc }[4,33]\end{array}$ & $\mathrm{NL}$ & 65 & 1706 & 3.8 & 3 & 184 & 1.6 \\
\hline $\begin{array}{l}\text { CHEK } 2 \text { Consortium 2004- } \\
\text { Helsinki[33] }\end{array}$ & Finland & 21 & 1035 & 2.0 & 26 & 1885 & 1.4 \\
\hline $\begin{array}{l}\text { CHEK } 2 \text { Consortium 2004- } \\
\text { Kuopio[4] }\end{array}$ & Finland & 13 & 464 & 2.8 & 5 & 447 & 1.1 \\
\hline $\begin{array}{l}\text { CHEK } 2 \text { Consortium 2004- } \\
\text { Heidelberg[4] }\end{array}$ & Germany & 2 & 601 & 0.3 & 1 & 650 & 0.2 \\
\hline $\begin{array}{l}\text { CHEK } 2 \text { Consortium 2004- } \\
\text { Hannover[4] }\end{array}$ & Germany & 11 & 985 & 1.1 & 1 & 401 & 0.2 \\
\hline Van Binst et al[36] & Belgium & 0 & 52 & 0.0 & 1 & 103 & 1.0 \\
\hline Baeyens et al[37] & Belgium & 1 & 100 & 1.0 & 0 & 50 & 0.0 \\
\hline Kleibl et al[38] & $\begin{array}{l}\text { Czech } \\
\text { republic }\end{array}$ & 3 & 688 & 0.4 & 2 & 730 & 0.3 \\
\hline Rashid et al[39] & Germany & 5 & 613 & 0.8 & 2 & 417 & 0.5 \\
\hline Cybulski et al[40] & Poland & 10 & 1978 & 0.5 & 6 & 2748 & 0.2 \\
\hline Einarsdottir et al[41] & Sweden & 19 & 1509 & 1.3 & 8 & 1334 & 0.6 \\
\hline Weisher et al[42] & Denmark & 16 & 1374 & 1.2 & 22 & 4633 & 0.5 \\
\hline BIGGS & Ireland & 5 & 903 & 0.6 & 1 & 1016 & 0.1 \\
\hline
\end{tabular}

